\title{
Determinants of consumers' preferences for local food: A comparison study from urban and rural areas in Indonesia
}

\author{
Poppy Arsil \\ Agricultural Technology Department, Faculty of Agriculture \\ Universitas Jenderal Soedirman, Purwokerto, Indonesia \\ Mark Brindal \\ University of Adelaide \\ School of Agriculture, Food and Wine, Australia \\ Kusmantoro Eddy Sularso \\ Altri Mulyani \\ Faculty of Agriculture \\ Universitas Jenderal Soedirman, Purwokerto, Indonesia
}

Keywords

attribute, consumer preference, factor analysis, local food, rural, urban

\begin{abstract}
Spatial factors (rural and urban) might influence consumer preferences towards local food. This study explores and compares consumer preferences for local food in the urban and rural context. Face to face interviews were conducted in urban and rural locations on Java island, Indonesia. Six hundred respondents were interviewed using a structural questionnaire. Factor analysis was applied to group consumers based on their preferences. Although consumer demographics differ, the results show that factors influencing consumers' preferences seem to be similar in term of "food quality", "support for local food", "availability", "promotion", "tradition", and "packaging ". "Food safety" also influences preferences for local food in urban areas. Though the paths by which the groups arrive at these motivators differ, the factors influencing consumer preference for local food are remarkably homogenous regardless of location. These results provide important implications for developing marketing strategies for local food linking urban and rural areas. Marketing can be enhanced through advertising and increasing consumer awareness and knowledge. This can be accomplished through mass media and formal and informal education, as well as traditional events. This study has its limitation that only one rural and one urban area was surveyed. Thus, these findings cannot be generalised for Indonesia as a whole. This paper's unique contribution is to explore and compare consumer preference for local food in urban and rural Indonesia.
\end{abstract}

Corresponding author: Poppy Arsil

Email addresses for corresponding author: poppy74arsil@gmail.com

First submission received: $2^{\text {nd }}$ March 2018

Revised submission received: $10^{\text {th }}$ May 2018

Accepted: 22 ${ }^{\text {nd }}$ May 2018

Introduction

In Indonesia increasing awareness and concern for local food has been a growing market trend. Emerging movements supporting local farmers such as the "toko tani" (farmers' shops) initiated by the Indonesian Agricultural Department and "lima kilo" (five kilos) -(a social movement to support local farmers by shortening the supply chain from farmers to consumers) are pointers to this movement. Since the 1960's, local food has been supported by government food diversification policies. This is specifically accomplished through Presidential Regulation (No. 22 of 2009). This regulation promulgates, in order to increase food variety and to provide nutritional sources of carbohydrates other than rice, the diversification of local food resources (Indonesian Agricultural Department, 2010).

Residents living in rural and urban locations exhibit differing consumer preferences towards local food. Although urban consumers are reported as having a positive preferences towards local food (Patterson et al., 1999), many previous studies have noted that rural consumers tend to have even higher 
levels of awareness and motivation to search for locally grown produce (Brown, 2003; Mirosa and Lawson, 2012; Roininen, Arvola and Lähteenmäki, 2006; Weatherell, Tregear and Allinson, 2003). This may be because rural residents are closer to local food sources and they may place more value on sociological and civic issues when making food purchasing decisions (Weatherell, Tregear and Allinson, 2003).

According to the World Bank (2016), the urbanization rate in Indonesia is $4.1 \%$ per year. It is predicted that $68 \%$ of the Indonesia population will be urbanised by 2025. Preference for local food in urban and rural locations will be influenced by this increasing demand for food and by population mobility. The average per-capita monthly expenditure for food in urban areas was $45 \%$ of the total household expenditure. It was 59\% in rural areas in 2015 (Statistics Indonesia, 2016). It is thus worthwhile to explore a comparison of consumers' preferences in rural and urban locations.

Scholars lack agreement on an exact definition of local food. However, most previous authoritative literature frequently defines "local" food through parameters such as "distance or travelling distance", "driving hours", "specific region" or "political boundaries" (Adams and Salois, 2010; Arsil, Li and Bruwer, 2014a; Chambers et al., 2007; Zepeda and Leviten-Reid, 2004). Distances ranging from 10-100 miles are variously deemed appropriate. Political boundaries ranged from states, to provinces and counties.

The driving factors affecting consumer interest in local food have been investigated in many studies. Notable among those factors are price (Arsil et al., 2014b; Brown, 2003; Kezis et al., 1998), food quality, freshness, taste and appearance (Arsil et al., 2014b; Adams and Adams, 2011; Brown, 2003; Chambers et al., 2007; Kezis et al., 1998; Zepeda and Deal, 2009). Other factors include support for the local economy and farmers, country of origin (Brown, 2003; Giraud et al., 2013; Memery et al., 2015; Kezis et al., 1998), ease of preparation (Arsil et al., 2014b), social environment (Conner et al., 2010), and environmental sustainability (Feldmann and Ham, 2015).

Other important attributes such as food origin, employment creation, farmer support, brand and availability have not yet been investigated in Asian countries (Moser, Raffaelli and Thilmany, 2011, p. 130). Previous studies have examined consumer preference for local food in Europe (e.g. Giraud et al., 2013; Brozzi et al., 2016; Tregear and Ness, 2010) and the US (e.g. Thilmany, Bond and Bond, 2008; Cholette et al., 2013). However, knowledge is scant regarding local food preference in developing countries.

Indonesia is a particularly interesting case study since it is an archipelago constituted by more than 300 ethnic groups. Local culture and tradition exhibit great diversity. Comparing consumers' preference for local food in the context of the diverse multi-ethnic groupings of Indonesia is a worthwhile investigation. The largest ethnic group in Indonesia is Javanese (approximately 42\%). Yogyakarta, the urban area in this study, is the capital of the Yogyakarta special region and was the Indonesian capital during the national revolution (from 1945 to 1949). A large majority of the population is Javanese by descent. Yogyakarta is the central hub of Javanese culture. However, due to its large number of schools and universities and its relatively low living costs, the city has also attracted large numbers of students both from other Indonesian regions and overseas. Many other Indonesian ethnics groups live in Yogyakarta, including people from the eastern parts of Indonesia. The Banyumas regency is a rural area located in the southwestern part of central Java. It is about $170 \mathrm{~km}$ from Yogyakarta city. The dominant ethnic population in the Banyumas regency is also Javanese.

As previously noted, residential location can be considered one of the determinant factors in respect to making decisions when purchasing locally produced food. This paper will extend the literature by examining local food preferences in rural and urban areas. It will explore and compare the motivation of urban and rural consumers and their preferences towards making food purchasing decisions for locally produced food. The results of this study will assist government, producers and traders to more successfully promote and create marketing strategies for local food.

\section{Review of consumer preferences towards local food}

Consumer preferences can be defined as those subjective personal tastes that allow consumers to refer to certain personal preference characteristics (Zikmund and Babin, 2010). Consumers, as individuals, have a set of preferences that, in turn, are dependent on product attributes and location. 
Brozzi et al. (2016) surveyed 498 consumers in South Tyrol (Italy) using both descriptive statistics and the Kruskal-Wallis test. They found that spatial typology (urban, predominantly urban and rural location) has a significant influence both on preferred store choice and on food expenditure, when purchasing local food.

Cultural background influences both the parameters which individuals apply as the determinants to identify local food and the relevant attributes that motivate local food purchase. Tregear and Ness (2005) conducted a survey among 734 respondents who lived in two urban and three rural locations in the North of England. They identified attitudinal factors followed by situational factors related to the dwelling place of residents (urban/rural). Additionally, they found the degree of involvement with farming to be a key determinant of consumer interest in buying locally produced food. Lockeretz (1986) interviewed 600 urban and suburban consumers in Massachusetts at an agricultural fair. This study suggested that purchasing directly from farmers within a short time of harvest (freshness) was important for consumers when purchasing local food. Penney and Prior (2014) conducted focus group among urban shoppers in Birmingham, UK. Their study identified that, although urban consumers were interested in local food, this predisposition did not automatically translate into purchasing behavior. Rather attributes related to quality, freshness and health are key considerations for consumers purchasing local food. Conversely, availability is one of the dominant determinants of consumer interest when buying local food. Depsite this, few studies have been undertaken to compare any differing attributes that influence consumer preference in urban and rural locations in Asian countries.

Many studies address desirable attributes related to local food. In general, freshness, quality and health issues are important to urban consumers (Penney and Prior, 2014). Likewise, Henseleit, Kubitzki and Teuber (2007) reported that quality and freshness were the most important reasons to buy regional food. However, regional consumers were unwilling to pay more. Regional food also has a positive relationship with food safety and in supporting local agriculture. In terms of socio/demographic factors, consumers who were members of environmental groups and who had achieved higher levels of education and income exhibited a higher willingness and to pay more for local food. Arsil et al. (2014b), using soft laddering, interviewed a total of 184 local food consumers from urban and rural areas on Java Island, Indonesia. The research identified two important attributes that motivated urban and rural consumers when purchasing local food. They were "inexpensive" and "food quality". In addition, ease of preparation and cooking were also important attributes for urban consumers when making purchasing decisions. Using a similar methodology, Roininen, Arvola and Lähteenmäki (2006), studying Mikkeli, as representative of an agricultural area in Findland and Espoo, part of Helsinki Metropolitan area, reported different cognitive structures motivating the purchase of locally produced food. The reason for local food preferences in Mikkeli was linked to consumer support for local production, employment creation and economic welfare. Conversely in urban Espoo, participants related local food to animal welfare, environmental good and health. It should be mentioned that the linkages between attributes and consequences were more concrete in the rural area by linking short transportation distances to "lower price", "good taste", "saving money" and "freshness". Urban participants related short transportation distances to "animal welfare" and "respect nature". The common attributes between both areas are 1) short transportation distance and 2) Finnish origin of products. That first attribute is linked to "freshness" and the second has an association with a sense of security.

Cholette et al. (2013) investigated purchasing preferences for local and ecologically labeled food among 428 students at the California State University. Their study centred around the consumer selection of apples based on a combination of price, and food source (in the absence of an ecological indicator). Through the use of factor analysis, the authors identified three consumer segments: the deep green, the price conscious and the switchers. The deep green tend to be more active in seeking information and variety than the price conscious. The factors contributing to local food preference have been shown to vary greatly between urban and rural settings. Consequently, this exploratory study will investigate determinant attributes for local food preferences by also considering other relevant factors (see Moser, Raffaelli and Thilmany, 2011).

Other researches have explored the reasons behind purchasing fresh food in farmers' markets. Tey et al. (2017) conducted soft laddering interviews among 212 shoppers at farmers' markets in the Klang 
Valley, Malaysia. They found that "fresh", "variety" and "cheap price" were important attributes when buyers purchase food. Kezis et al. (1998) reported three main reasons for consumer shopping at farmers' markets: "quality of product", "support local farmers" and "friendly atmosphere." Respondents were willing to pay more for local food sold at farmers' markets when compared to similar foodstuffs sold in supermarkets. Gallons et al. (1997) mentioned as the primary reasons for purchasing fresh products directly from markets: "produce selection", "locally grown", "like to help farmers" and "money back guarantee" (Gallons et al., 1997).

Moser, Raffaelli and Thilmany (2011) reviewed 40 publications related to consumer preferences for organically grown and locally produced fruit and vegetables in the US, Canada, Argentina and Australia. The research indicated the main determinants to be "health", "visual and smell", "environmental concerns", "pesticide free", "local", "support farmers" and "quality". In addition, strong determinants for niche products in East Asia/Pacific Rim were "health benefits" and "environmental concerns" while a less dominant attribute was price. Attributes that have not been investigated include 1) certification, 2) support farmers, 3) origin and local, 4) creation of employment, 5) brand and 6) availability. Given that a wide spectrum of determinant factors have been identified by researchers working globally, the question remains as to whether there are different drivers that have not been investigated in Asian countries, and, in particular, in Indonesia. Might the uninvestigated attributes mention by Moser, Raffaelli and Thilmany (2011) influence consumers' interest for local food in Indonesia? If they do, to what extent and how important are they to the consumer decision making process? Our study, of over 600 respondents from urban and rural areas in Indonesia adds to the body of knowledge and attempts to answer these questions.

This paper is organized as follows. We have already discussed previous studies relating to local food preferences. Section 3 sets out the data collection and analysis procedure. The results are presented. They are followed by a discussion of the results. The final section summarizes the results, discusses potential implications, set out study limitations and suggests areas requiring further research.

\section{Methods \\ Data collection procedure}

In concurrence with the Regulation of the Central Bureau of Statistics (Number 37 of 2010) with respect to classification of rural and urban areas in Indonesia, a special region of Yogyakarta was selected as our urban area. The Banyumas Regency was chosen as representative of a rural area. Research for this study was conducted in two phases. In order to obtain an initial understanding of consumer preference for local food, the first stage was an exploratory study that focussed on group discussion. Two focus groups were conducted in Yogyakarta and the Banyumas Regency. Participants were selected from the researcher's social networks (relatives, friends, collages, neighbours). They were asked to identify other potential participants. They were then invited to join the group discussion. Factors influencing consumer preference were similar to those found by earlier studies. Exceptions were "traditional custom", "packaging", "promotion" and "experience the way of cooking". For example, one respondent said that "It is our family culture to provide local food such as boiled sweet potatoes and banana every morning. It seems the day is incomplete if I fail to serve my family with those foods".

The second phase was to conduct face-to-face interviews. The questionnaire consisted of six topics involving 1) quality, 2) experience/tradition, 3) motivation to purchase local food, 4) price, 5) packaging, 6) availability and promotion (the survey is available upon request). Respondents were also asked about their socio-demographic characteristics and perceptions about their locality. We ascertained their ethnic group and asked about purchasing behaviour in order to explore any significant differences in the characteristic of urban and rural residents. A pre-test questionnaire was used to clarify the questionnaire's wording and to check its suitability. Structured questionnaires used a five Likert-scale between 1 (strongly disagree) and 5 (strongly agree). Data for this study was collected using a structural questionnaire developed from previous studies (Brown, 2003; Bruhn et al., 1992; Lockeretz, 1986; Patterson et al., 1999). In the absence of any empirical literature with respect to local food preferences, the results of focus group discussions and the attributes identified (Moser, Raffaelli and Thilmany, 2011) were included.

Data was collected between April and June 2017. Six trained interviewers approached consumers in urban (Yogyakarta) and rural (Banyumas) areas. Respondents were selected using multistage sampling. 
Two of the most densely populated subdistricts were selected and two villages were chosen for each selected subdistrict Three neighbourhood areas were selected based on population density and respondents were approached systematically starting from the first to the $5^{\text {th }}$ element on the list. They were asked whether they were a "food decider" for their household and whether they had purchased local food in the past week. The sample was selected from those above 17 years of age since we wished to be certain that they had acquired appropriate consumer knowledge. A total of 600 respondents were interviewed. The response rate was 92 percent.

\section{Data analysis}

Descriptive analysis was used to obtain a picture of the socio/demographics. Standard factor analysis was used to allow the identification of factors behind local food purchase decision making. A Nomograph was used to determine the percentage difference between the two groups of consumers (Oppenheim, 1992). Steps taken in factor analysis included Kaiser-Meyer-Olkin (KMO) and Bartlett's Test of Sphericity (in order to determine the sampling adequacy). KMO values range from 0 to 1 with an acceptable index above 0.6. For the Bartletts's test of Sphericity, the value should be less than 0.5. This confirms the validity and suitability of the data and allows the subsequent steps in factor analysis to be undertaken. The next step is a communalities analysis, which is used to calculate the sum of the variance. Varimax rotation factor analysis is done to obtain simple and interpretable factors (Hair et al., 2009).

\section{Results}

Socio-demography urban and rural consumers

In general, the main respondents to this study were female (as are the majority of food decision makers in Indonesia (e.g. Arsil, Li and Bruwer, 2014a) and housewives. Urban respondents were more diverse in their ethnicity and tended to have higher education levels when compared to their rural counterparts. They tended to spend less of their total available budget on weekly food purchases. This is congruent with Statistics Indonesia (2016).

Men were more involved in local food decision making in urban areas. Rural respondents purchased food more frequently. They bought local food and spent more a higher proportion their total available budget on food. Around sixty one percent of rural residents sourced local food at traditional markets. Table 1 displays a comparison between respondent characteristics in urban and rural areas.

\begin{tabular}{|c|c|c|c|c|c|}
\hline \multirow[t]{2}{*}{ Characteristics } & \multirow[t]{2}{*}{ Categories } & \multicolumn{2}{|c|}{$\begin{array}{l}\text { Urban area } \\
(\mathrm{N}=300)\end{array}$} & \multicolumn{2}{|c|}{ Rural area $(\mathrm{N}=300)$} \\
\hline & & Person & Percentage & Person & Percentage \\
\hline \multirow{4}{*}{ Age (year old) } & $<30$ & 83 & 28 & 87 & 29 \\
\hline & $=30-<40$ & 105 & 35 & 82 & 28 \\
\hline & $=50-<60$ & 29 & 10 & 51 & $17^{*}$ \\
\hline & $=60$ & 16 & 5 & 12 & 4 \\
\hline Gender & Male & 49 & 16 & 9 & $3 *$ \\
\hline \multirow[t]{3}{*}{ Education } & Primary school & 12 & 4 & 53 & $18 *$ \\
\hline & High school & 144 & 48 & 154 & 51 \\
\hline & University & 144 & 48 & 93 & $31 *$ \\
\hline \multirow{6}{*}{ Occupation } & Civil servant & 37 & 12 & 14 & $5^{*}$ \\
\hline & Entrepreneur & 61 & 20 & 83 & $28^{*}$ \\
\hline & Housewives & 102 & 34 & 138 & $46^{*}$ \\
\hline & Farmex & $\mathbf{O}$ & O & 37 & $12^{\star}$ \\
\hline & Student & 26 & 9 & 3 & $I^{*}$ \\
\hline & Employer & 74 & 25 & 28 & $9^{*}$ \\
\hline \multirow{2}{*}{ Ethnic group } & Java & 263 & 88 & 284 & $95^{*}$ \\
\hline & Non-Java & 37 & 12 & 16 & $5^{\star}$ \\
\hline \multirow{4}{*}{$\begin{array}{l}\text { Family income } \\
\text { (million IDR) }\end{array}$} & $=3$ & 189 & 63 & 205 & 68 \\
\hline & $>3-=6$ & 74 & 25 & 66 & 22 \\
\hline & $>6-=9$ & 7 & 2 & 14 & 5 \\
\hline & $>9$ & 30 & 10 & 15 & $5^{*}$ \\
\hline \multirow{3}{*}{$\begin{array}{l}\text { Food expenditure } \\
\text { for food a week } \\
\text { (OOO IDR) }\end{array}$} & $>200-=400$ & 232 & 77 & 194 & $64 *$ \\
\hline & $>400-=800$ & 60 & 20 & 90 & $30^{*}$ \\
\hline & $=800$ & 8 & 3 & 16 & 4 \\
\hline \multirow{3}{*}{$\begin{array}{l}\text { Frequency } \\
\text { buying local food }\end{array}$} & $2-7$ times a week & 219 & 73 & 252 & $84^{\star}$ \\
\hline & Once a week & 160 & 20 & 27 & $9^{*}$ \\
\hline & Others & 21 & 7 & 21 & 7 \\
\hline \multirow[t]{4}{*}{$\begin{array}{l}\text { Place buying local } \\
\text { food }\end{array}$} & $\begin{array}{l}\text { Traditional } \\
\text { market }\end{array}$ & 123 & 41 & 183 & $61 *$ \\
\hline & Modern market & 84 & 28 & 27 & $9^{*}$ \\
\hline & Pitchman & 54 & 18 & 21 & $7 *$ \\
\hline & Warung/kiosks & 38 & 13 & 69 & $23^{\star}$ \\
\hline \multirow{3}{*}{$\begin{array}{l}\text { Food expenditure } \\
\text { for local food a } \\
\text { week (OOO IDI) }\end{array}$} & $=200$ & 195 & 65 & 174 & 58 \\
\hline & $=400$ & 75 & 25 & 93 & $31 *$ \\
\hline & $>400$ & 30 & 10 & 33 & 11 \\
\hline
\end{tabular}


* Significant value is 0.082 at N1=300 and N2=300. The two sets of percentage will be different if the value obtained from nomograph at 0.1 confidence interval exceeded the significant value (Oppenheim, 1992 p.294-297).

Characteristics may not sum to $100 \%$ due to rounding

Table 1. Respondents' profiles of local food consumers in urban and rural area

Urban area

The result of KMO is 0.852 that confirms the sampling adequacy exceeded 0.5. Bartlett's Test is significant (sig 0.000). This means that valid factor analysis can be carried out. Furthermore, six latent factors are identified namely: 1) quality of food, 2) support local food and ethnocentrism, 3) food appearance and taste, 4) availability, 5) promotion, and 6) food safety and tradition. In the context of principal component analysis, the scree plot of the eigenvalues can be used to decide the number of factors to be retained by using eigenvalues $>1$ (Hair et al., 2009). Figure 1 presents the scree plot of the eigenvalues of the first 24 factors. Table 2 presents a summary of that factor analysis. 


\begin{tabular}{|c|c|c|c|c|c|c|}
\hline \multirow[t]{2}{*}{ Statements } & \multicolumn{6}{|c|}{ Factor loading } \\
\hline & F1 & F2 & F3 & $\mathrm{F} 4$ & F5 & F6 \\
\hline \multicolumn{7}{|l|}{ F1. Quality of food } \\
\hline More nutritious & 0.809 & & & & & \\
\hline Natural & 0.799 & & & & & \\
\hline Healthier & 0.781 & & & & & \\
\hline Fresher & 0.754 & & & & & \\
\hline Good quality & 0.596 & & & & & \\
\hline Total variance explained (\%) & 14.513 & & & & & \\
\hline \multicolumn{7}{|c|}{ F2. Support local food and ethnocentrism } \\
\hline Support local economy & & 0.839 & & & & \\
\hline Support local food & & 0.814 & & & & \\
\hline Proud eating local food & & 0.814 & & & & \\
\hline Total variance explained (\%) & & 14.432 & & & & \\
\hline \multicolumn{7}{|l|}{ F3. Food appearance and taste } \\
\hline Good appearance of food & & & 0.783 & & & \\
\hline Good taste & & & 0.710 & & & \\
\hline Special taste & & & 0.627 & & & \\
\hline No packaging & & & 0.613 & & & \\
\hline Total variance explained (\%) & & & 11.317 & & & \\
\hline \multicolumn{7}{|l|}{ F4. Availability } \\
\hline Available during the year & & & & 0.748 & & \\
\hline Local food is easier to find & & & & 0.732 & & \\
\hline Cheaper price & & & & 0.668 & & \\
\hline Assurance of product origin & & & & 0.577 & & \\
\hline Total variance explained (\%) & & & & 10.299 & & \\
\hline \multicolumn{7}{|l|}{ F5. Promotion } \\
\hline $\begin{array}{l}\text { Promotion through government } \\
\text { activities }\end{array}$ & & & & & & \\
\hline $\begin{array}{l}\text { Promotion through television or } \\
\text { mass media }\end{array}$ & & & & & 0.815 & \\
\hline $\begin{array}{l}\text { I have enough knowledge from } \\
\text { formal and informal education }\end{array}$ & & & & & 0.578 & \\
\hline Total variance explained (\%) & & & & & 8.703 & \\
\hline \multicolumn{7}{|l|}{ F6. Food safety and tradition } \\
\hline Free from chemical pesticides & & & & & & 0.650 \\
\hline Easy and fast to make & & & & & & 0.638 \\
\hline Family tradition eating local food & & & & & & 0.579 \\
\hline Family eats local food & & & & & & 0.542 \\
\hline Total variance explained (\%) & & & & & & 8.679 \\
\hline Total percentage of variance & & & & & & 67.942 \\
\hline Initial Eigenvalues & 7.658 & 2.457 & 2.010 & 1.807 & 1.339 & 1.036 \\
\hline
\end{tabular}

Table 2. Summary of factor analysis results of consumers who live in urban area

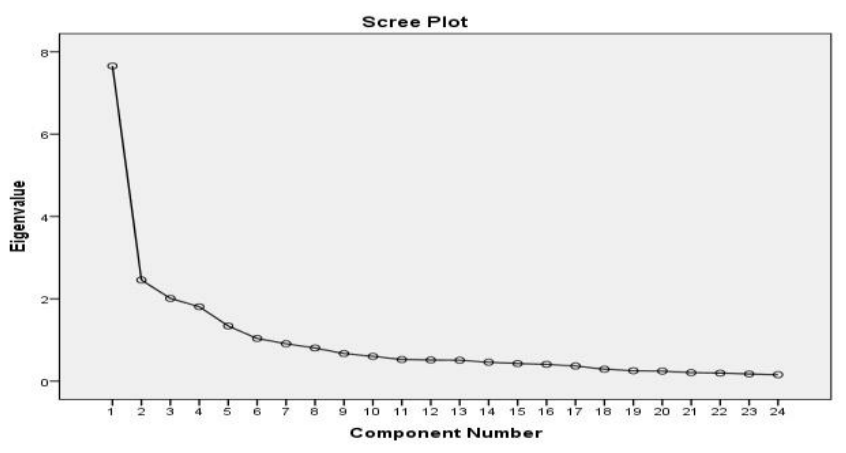


Figure 1. Scree plot of eigenvalues for local food preferences in urban areas

The first factor leads positively to food quality and, in particular, to such product attributes as nutrition, natural product, healthiness, freshness. Total variance for this factor is $14.513 \%$, with the highest rotational loading factor "more nutrition" (0.809). The second factor is dominated by "supporting local food and ethnocentrism". The third factor, in addition, leads to "food appearance and taste" This encompasses firmness, texture, color and taste. The variance is $14.432 \%$. The next dimension represents "availability". Embodied in this factor is availability and ease of access, as well as cheap price. Each of these factors has positive connections to local food. The fifth factor might be termed "promotion through mass media, government activities and through formal and informal educative processes". A new dimension emerged as the last factor. It may be termed "food safety and tradition" and it is positively associated with foodstuffs that are free from chemical pesticides. Tradition represent habitual daily routine. These six factors accounted for $67.942 \%$ of the variability of the sample. This result is acceptable within valid constructs (Hair et al., 2009).

Rural area

The KMO resulted in a score of 0.843 and is significant (sig. 0.000). This indicates that the sample is adequate, and that valid factor analysis could be conducted. A summary of the factor analysis results shows the formation of six latent factors with a total variance of $59.964 \%$ (Table 3). These are 1) "food quality", 2) "availability", 3) "promotion", 4) "tradition", 5) "support local food", and 6) "packaging" while Figure 2 depicts the scree plot of the eigenvalues of local food preferences in the rural study area.

\begin{tabular}{|c|c|c|c|c|c|c|}
\hline \multirow[t]{2}{*}{ Statements } & \multicolumn{6}{|c|}{ Factor loading } \\
\hline & F1 & F2 & F3 & F4 & F5 & F6 \\
\hline \multicolumn{7}{|l|}{ F1. Quality of local food } \\
\hline More nutritious & 0.842 & & & & & \\
\hline Healthier & 0.800 & & & & & \\
\hline Natural & 0.753 & & & & & \\
\hline Good quality & 0.721 & & & & & \\
\hline Fresher & 0.704 & & & & & \\
\hline Good taste & 0.564 & & & & & \\
\hline Total variance explained (\%) & 17.325 & & & & & \\
\hline \multicolumn{7}{|l|}{ F2. Availability } \\
\hline Available during the year & & 0.765 & & & & \\
\hline Local food is easier to find & & 0.726 & & & & \\
\hline Assurance of product origin & & 0.715 & & & & \\
\hline Cheaper price & & 0.576 & & & & \\
\hline Total variance explained (\%) & & 10.428 & & & & \\
\hline \multicolumn{7}{|l|}{ F3. Promotion } \\
\hline Promotion through government & & & 0.746 & & & \\
\hline activities & & & 0.693 & & & \\
\hline Promotion through mass media & & & 0.693 & & & \\
\hline I have enough knowledge about local & & & & & & \\
\hline $\begin{array}{l}\text { food from formal or informal } \\
\text { education }\end{array}$ & & & & & & \\
\hline Total variance explained (\%) & & & 9.127 & & & \\
\hline \multicolumn{7}{|l|}{ F4. Tradition } \\
\hline Family tradition eating local food & & & & 0.753 & & \\
\hline Fast and easy to make & & & & 0.721 & & \\
\hline Family eats local food & & & & 0.670 & & \\
\hline Total variance explained (\%) & & & & 8.857 & & \\
\hline \multicolumn{7}{|l|}{ F5. Support local food } \\
\hline Support local food & & & & & 0.832 & \\
\hline Support local economy & & & & & 0.755 & \\
\hline Proud eating local food & & & & & 0.564 & \\
\hline Total variance explained (\%) & & & & & 8.638 & \\
\hline \multicolumn{7}{|l|}{ F6. Packaging } \\
\hline Nopackaging & & & & & & 0.864 \\
\hline Total variance explained (\%) & & & & & & 5.588 \\
\hline Total percentage of variance & & & & & & 59.964 \\
\hline Initial Eigenvalues & 6.698 & 2.048 & 1.863 & 1.399 & 1.283 & 1.101 \\
\hline
\end{tabular}

Table 3. Summary of factor analysis results of consumers who live in rural area 


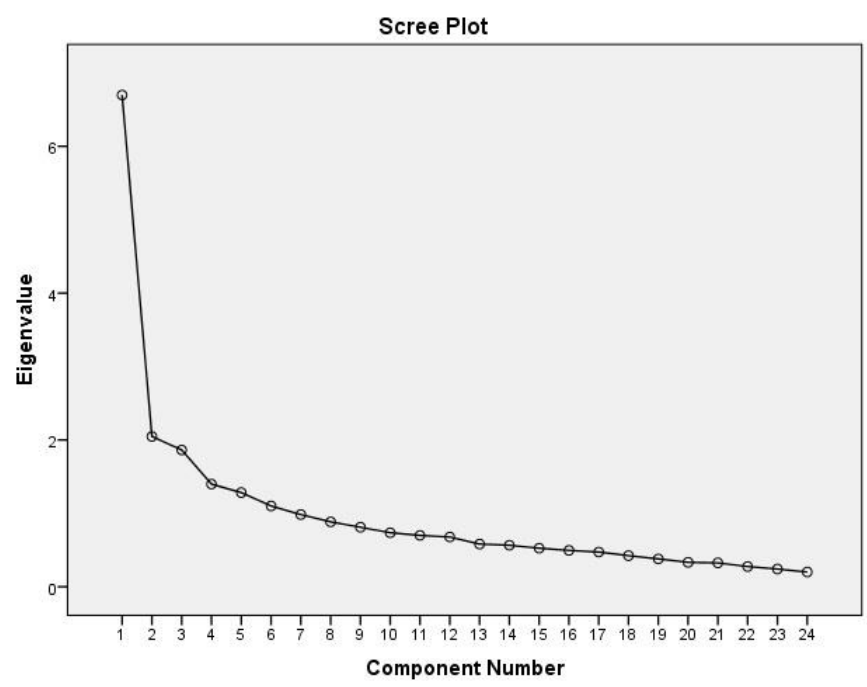

Figure 2. Scree plot of eigenvalues for local food preferences in rural areas

The first dimension is dominated by a quality dimension and is positively correlated with nutrition, healthiness, naturalness, and freshness. This factor has a total variance of 17.325 and comprises six sub-variables. The highest rotated loading factor is "more nutritious" (0.842). The second factor is linked positively to "availability" and "location of production". The highest rotation loading is "local food is easier to find". All dimensions are positively correlated to local food. A third factor might be termed "promotion". It consists of three sub-variables. The highest loading factor is "promotion through government activities" (0.746). Tradition, related to preparing and eating daily food, also emerged in the fourth factor. The factor has a total variance of 8.857. "Support local food" is identified as the fifth dimension. This relates positively to supporting local food and local economy as well as to ethnocentrism. The last factor, "packaging", explains $5.588 \%$ total variance. It has only one sub-variable. Total variance explained is approximately $60 \%$. This is acceptable for valid constructs (Hair et al., 2009).

\section{Discussion}

A "Support local food movement" has been growing in Indonesia. This is, in part, as a consequence of a social movement supporting farmers and the local economy. The goal of this study is to identify attributes that determine the preference for local food in urban and rural areas. Our analysis provides important results. First, preference for local food is driven by similar motivators in urban and rural areas. Specifically, commonalities related to attributes involving "quality of products" support local food", "availability" and "promotion". "Quality of food" is a main determinant factor. It explains 17.325\% of the variance in our urban areas and $14.513 \%$ in our rural area. For both resident groups, local food is believed to be fresher, more nutritious and of higher quality than non-local food. As local produce is grown and harvested closer to consumers, the travel time and spoilage caused during transportation is diminished. This is believed to have a positive association with food quality, food appearance and nutrition. This result is also relevant to previous research, which mentions local food as being thought to be of higher quality than non-local food (Arsil, Li and Bruwer, 2014a; Brown, 2003; Kezis et al., 1998; Moser, Raffaelli and Thilmany, 2011). Comparably, Darby et al. (2008) also reported that local food was thought to have a good and special taste and to be superior in appearance in terms of color, shape, and texture. Visual appeal and smell are also strong determinant attributes for niche products. These are included in local and organic food preferences for fruit and vegetables in Europe (Moser, Raffaelli and Thilmany, 2011).

"Support for local food" is a more important factor for urban consumers (variance 14.432) than for their rural counterparts. According to "Statistics Indonesia", average land ownership by local farmers in Indonesia is less than one hectare. Buying and eating local food benefits the local economy in terms underpinning the economic viability of small farmers and contributing to local businesses. Eating local 
food also benefits the maintenance of local resources. Local food is also associated with pride. These results are similar to previous studies that have reported that respondents view local food production to be associated with supporting farmers and local agriculture (Arsil, Li and Bruwer, 2016; Roininen, Arvola and Lähteenmäki, 2006; Zepeda and Leviten-Reid, 2004).

"Availability" is an important dimension in local food preference. As reported by Zepeda and Levite-Zein (2004) a lack of availability of local food can be a potential barrier for consumers and necessarily has a negative impact on local food consumption. Perceptions of a lack of availability might be also related to deficiencies in product labelling. Although local food might be available in the market, consumers will have difficulty identifying it unless it is appropriately labelled. This could influence consumer preference (Feldmann and Hamm, 2015). Both groups perceive local food as being available throughout the year and agree that the food available is, generally, cheaper. The aforementioned factors are frequently noted attributes identified in previous studies addressing local food preferences (e.g. Adams and Adams, 2011; Penney and Prior, 2014; Zepeda and Deal, 2009; Moser, Raffaelli and Thilmany, 2011).

Three other dimensions, "promotion", "tradition" and "packaging" have not been widely investigated in Asian countries. Promotion becomes an important factor in consumer preference in both areas of study. Effective channels in the promotion of local food can include Government activities such as agricultural and food exhibitions, nutrition campaigns and promotion through television or other mass media. Additionally, consumer knowledge through educative processes can be have a beneficial effect on attitudes towards local food. Tradition is another dimension in local food preference. This is not surprising, since it is common in Indonesia to provide specific local foods such as steamed peanuts, cassava, banana or sweet potatoes as a daily staple. People are also familiar with and enjoy cooking using traditional recipes that have been passed from generation to generation. Such recipes often rely on using local resources as ingredients. Consumers associate the purchase of local food with lower costs. This finding is consistent with previous research in Indonesia (Arsil, Li and Bruwer, 2016; Arsil et al., 2014b). Cheaper prices result from the proximity of local food and to the fact that no packaging or preservative processes (such as cold chains) are involved. One difference between urban and rural consumers is that urban consumers place importance on "food safety" and consider "local food to be free from chemical pesticides (0.52)". However, this finding might contain bias due to differing perceptions of the concepts "local" and "organic" food.

\section{Conclusions}

When making the decision to purchase local food, food quality, support for local food, availability, promotion and tradition are the common attributes shared by both urban and rural consumers. In addition, urban consumers are concerned with food safety. Marketing campaigns to increase sales of locally grown food are believed to be the most effective way to promote local food. Advertising should leverage known attributes, such as quality, support local food, and availability. Slogans such as "fresher and more nutritious, buy local" and "proudly eating local food" are suggested. In order to increase consumer knowledge, Government activities such as agricultural exhibitions, nutritional campaigns and empowering family welfare development groups, should have local food programs included in them. A suitable program might be also added to the local curriculum (from primary to senior high school) in order to educate the next generation of consumers. As local food is a part of local tradition, it can be promoted through such traditional events as religious and customary holidays. The last recommendation is the introduction and use of simple logos representing "locally grown". Logos should be clearly labelled so that consumers can easily identify local food products.

This study has the limitation that only one urban and one rural area on Java Island was researched. The results of this study cannot, therefore, be safely extrapolated for all Indonesian consumers. Future research should be done to include different ethnic groups, a diversity of rural areas, and/or big cities like Jakarta, Medan and Surabaya.

\section{Acknowledgement}


We thank Ministry of Research, Technology and Higher Education of the Republic of Indonesia (Contract no. 068/SP2H/LT/DRPM/IV/2017) for the funding, along with Institute for Research and Community Service, Universitas Jenderal Soedirman for financial supported for proofreading services.

\section{References}

Adams, D. C. and Adams, A. E. (2011). De-Placing Local at the Farmers' Market: Consumer Conceptions of Local Foods. Journal of Rural Social Sciences, 26(2), pp. 74-100.

Adams, D. C. and Salois, M. J. (2010). Local Versus Organic: A Turn in Consumer Preferences and Willingness-to-pay. Renewable Agriculture and Food Systems, 25(4), pp. 331-341.

Arsil, P., Li, E. and Bruwer, J. (2014a). Perspectives on Consumer Perceptions of Local Foods: A View from Indonesia. Journal of International Food \& Agribusiness Marketing, 26(2), pp. 107-124.

Arsil, P. Li, E., Bruwer, J. and Lyons, G. (2014b). Exploring Consumer Motivations towards Buying Local Fresh Food Products: A Means-End Chain Approach. British Food Journal, 116(10), pp. 1533-1549.

Arsil, P., Li, E. and Bruwer, J. (2016). Using Means-End Chain Analysis to Reveal Consumers' Motivation for Buying Local Foods: An Exploratory Study. Gadjah Mada International Journal of Business, 18(3), pp. 285-300.

Brown, C. (2003). Consumers' Preferences for Locally Produced Food: A study in Southeast Missouri. American Journal of Alternative Agriculture, 18(4), pp. 213-224.

Brozzi, R., Stawinoga, A. E., Hoffmann, C. and Streifeneder, T. (2016). Determinants of Local Food Purchase: Insight from a Consumer Survey in South Tyrol (Italy). Socio.hu, 4(Special Issues in English), pp. 99-115.

Bruhn, C. M., Vossem, P. M., Chapman, E. and Vaupel, S. (1992). Consumer Attitudes toward Locally Grown Produce. California Agriculture, 46(4), pp. 13-16.

Central Bureau of Statistics. 2010. Regulation No. 37 of 2010 regarding Classification of Rural and Urban Areas in Indonesia (Peraturan Kepala Badan Pusat Statistik No. 37 Tahun 2010 tentang Klasifikasi Perkotaan dan Perdesaan di Indonesia). Jakarta: Statistics Indonesia.

Chambers, S., Lobb, A., Butler, L., Harvey, K. and Traill, W.B. (2007). Local, National and Imported Foods: A Qualitative Study. Appetite, 49(1), pp. 208-213.

Cholette, S., Özlük, Ö., Özşen, L. and Ungson, G.R. (2013). Exploring Purchasing Preferences: Local and Ecologically Labelled Foods. Journal of Consumer Marketing, 30(7), pp. 563-572.

Conner, D., Colasanti, K., Ross, R.B. and Smalley, S.B. (2010). Locally Grown Foods and Farmers Markets: Consumer Attitudes and Behaviors. Sustainability, 2(3), pp. 742-756.

Darby, K., Batte, M.T., Ernst, S. and Roe, B. (2008). Decomposing Local: A Conjoint Analysis of Locally Produced Foods. American Journal of Agricultural Economics, 90(2), pp. 476-486.

Feldmann, C. and Hamm, U. (2015). Consumers' Perceptions and Preferences for Local Food: A Review. Food Quality and Preference, 40(A), pp. 152-164.

Gallons, J., Toensmeyer, U. C., Bacon J. R. and German G. L. (1997). An Analysis of Consumer Characteristics Concerning Direct Marketing of Fresh Produce in Delaware: A Case Study. Journal of Food Distribution Research, 28(1), pp. 98-106.

Giraud, G., Amblard, C., Thiel, E., Zaouche-Laniau, M., Stojanović, Z., Pohar, J., Butigan, R., Cvetković, M., Mugosa, B., Kendrovski, V., Mora, C. and Barjolle, D. (2013). A Cross-Cultural Segmentation of Western Balkan Consumers: Focus on Preferences toward Traditional Fresh Cow Cheese. Journal of the Science of Food and Agriculture, 93(14), pp. 3464-72.

Hair Jr., J.F., Black, W.C., Babin, B.J. and Anderson, R.E. (2009). Multivariate data analysis. 7th Ed. Upper Saddle River: Prentice Hall, 761.

Henseleit, M., Kubitzki, S. and Teuber, R. (2007). Determinants of Consumer Preferences for Regional Food. In: the 105th EAAE Seminar 'International Marketing and International Trade of Quality Food Products', Bologna-Milano: Edizioni Avenue media. pp. 55-67, Available at https://ageconsearch.umn.edu/bitstream/7871/1/ cp070004.pdf, [accessed 12 March 2015].

Indonesian Agricultural Department. (2010). General guidance: Accelerating Indonesia's local food movement (Pedoman umum: Percepatan gerakan pangan lokal di Indonesia). Jakarta: Indonesian Agricultural Department.

Kezis, A. S., Gwebu, T., Peavey, S. R., and Hsiang-Tai, C. (1998). A Study of Consumers at A Small Farmers' Market in Maine: Results from A 1995 Survey. Journal of Food Distribution Research, 29, pp. 91-99.

Lockeretz, W. (1986). Urban Consumers' Attitudes towards Locally Grown Produce. American Journal of Alternative Agriculture, 1(2), pp. 83-88.

Memery, J., Angell, R., Megicks, P. and Lindgreen, A. (2015). Unpicking Motives to Purchase Locally-Produced Food: Analysis of Direct and Moderation Effects. European Journal of Marketing, 49 (7/8), pp. 1207-1233.

Mirosa, M. and Lawson, R. (2012). Revealing the Lifestyles of Local Food Consumers. British Food Journal, 114(6), pp. 816-825. 
Moser, R., Raffaelli, R. and Thilmany, D. D. (2011). Consumer Preferences for Fruit and Vegetables with CredenceBased Attributes: A Review. International Food and Agribusiness management Review, 14, pp. 121-142.

Oppenheim, A.N. 1992. Questionnaire design, interviewing and attitude measurement. London: Pinter Publisher Limited.

Patterson, P. M., Olofsson, H., Richards, T. J. and Sass, S. (1999). An Emperical Analysis of State Agricultural Product Promotions: A Case Study on Arizona Grown. Agribusiness, 15(2), pp. 179-196.

Penney, U and Prior, C. (2014). Exploring the Urban Consumer's Perception of Local Food. International Journal of Retail \& Distribution Management, 42(7), pp. 580-594.

Roininen, K., Arvola, A. and Lähteenmäki, L. (2006). Exploring Consumers' Perceptions of Local Food with Two Different Qualitative Techniques: Laddering and Word Association. Food Quality and Preference, 17(1-2), pp. 2030.

Statistics Indonesia. 2016. Statistical yearbook of Indonesia 2015 (Statistik Indonesia 2015). Jakarta: Statistics Indonesia.

Tey, Y. S., Arsil, P., Brindal, M., Teoh, C. T. and Lim, H. W. (2017). Motivations Underlying Consumers' Preference for Farmers' Markets in Klang Valley: A Means-End Chain Approach. Sustainability, 9(11), pp. 1-13.

Thilmany, D., Bond, C. A. and Bond, J. K. (2008). Going Local: Exploring Consumer Behavior and Motivations for Direct Food Purchases. American Journal of Agricultural Economics, 90(5), pp. 1303-1309.

Tregear, A. and Ness, M. (2005). Discriminant Analysis of Consumer Interest in Buying Locally Produced Foods. Journal of Marketing Management, 21 (1-2), pp. 19-35.

Weatherell, C., Tregear, A. and Allinson, J. (2003). In Search of the Concerned Consumer: UK Public Perceptions of Food, Farming and Buying Local. Journal of Rural Studies, 19(2), pp. 233-244.

World Bank. (2016). Indonesia's urban story. available at

http://www.worldbank.org/en/news/feature/2016/06/14/indonesia-urban-story [accessed 1 Feb. 2018].

Zepeda, L. and Deal, D. (2009). Organic and Local Food Consumer Behaviour: Alphabet Theory. International Journal of Consumer Studies, 33(6), pp. 697-705.

Zepeda, L. and Leviten-Reid, C. (2004). Consumers' Views on Local Food. Journal of Food Distribution Research, 35(3), pp. 1-6.

Zikmund, W.G. and Babin, B.J. (2010). Essentials of marketing research. 9 ${ }^{\text {th }}$ edition. Ohio: South-Western Cengage Learning. 